\title{
Smoking during Pregnancy Is a Risk Factor for Executive Function Deficits in Preschool-aged Children
}

\author{
Nikotinkonsum während der Schwangerschaft als Risikofaktor für Defizite \\ in exekutiven Funktionen im Kindergartenalter
}

Authors

Affiliation
M. Daseking, F. Petermann, T. Tischler, H.-C. Waldmann

Zentrum für Klinische Psychologie und Rehabilitation, Universität Bremen, Bremen

\author{
Key words \\ - nicotine \\ - pregnancy \\ - executive functions \\ - ADHD \\ - BRIEF-P \\ Schlüsselwörter \\ - Nikotin \\ - Schwangerschaft \\ - exekutive Funktionen \\ - ADHS \\ - BRIEF-P
}

Deutschsprachige Zusatzinformationen online abrufbar unter: www.thieme-connect.de/ ejournals/toc/gebfra

$\begin{array}{ll}\text { received } & 20.6 .2014 \\ \text { revised } & 11.11 .2014 \\ \text { accepted } & 12.11 .2014\end{array}$

Bibliography

DOI http://dx.doi.org/

10.1055/s-0034-1383419

Geburtsh Frauenheilk 2015; 75 : 64-71 ๑ Georg Thieme Verlag KG Stuttgart · New York. ISSN 0016-5751

\section{Correspondence}

\section{PD Dr. Monika Daseking}

Universität Bremen

Zentrum für Klinische

Psychologie und Rehabilitation

Grazer Straße 6

28359 Bremen

daseking@uni-bremen.de

\section{Abstract}

v

Introduction: Maternal nicotine use during pregnancy has a negative impact on the child. Numerous studies have demonstrated an association between smoking during pregnancy and psychological deficits. This study looks at deficits in executive functioning in preschool-aged children.

Methods: The executive functioning of preschool children was assessed by asking parents to complete the parental form of the Behavior Rating Inventory of Executive Functions - Preschool Version (BRIEF-P, German version). The results for preschool children whose mothers had smoked during pregnancy $(n=71)$ were compared with those of a control group. In a subsample, parental assessments of children of smokers $(n=42)$ and non-smokers ( $n=27$ ) were complemented by the teacher form of the BRIEF-P (German version), which allowed inter-rater agreement (parents vs. preschool teachers) to be assessed.

Results: An increased incidence of executive function deficits was noted in the children of smokers, based on parental assessment. Clinically relevant deficits were particularly evident with regard to inhibition, with inhibitory deficits in children of smokers found to be almost four times higher than in the control group $(\mathrm{p}=0.006)$. Inhibitory deficits were reported both by parents and by preschool teachers.

Discussion: The increased percentage of executive function deficits described here, particularly the increased inhibitory deficits, confirms the current state of research on smoking during pregnancy. Poor inhibition or impulse control is a key symptom of ADHD.

\section{Zusammenfassung \\ $\nabla$}

Einleitung: Der Nikotinkonsum der Mutter während der Schwangerschaft hat verschiedene negative Folgen für ein Kind. Eine Vielzahl von Studien zeigt dabei auch einen Zusammenhang mit psychischen Verhaltensauffälligkeiten auf. In der vorliegenden Studie soll der Fokus auf Störungen in den exekutiven Funktionen im Kindergartenalter gelegt werden.

Methoden: Es wurden die Eltern- und Erziehereinschätzungen zu exekutiven Funktionen im Verhaltensinventar zur Beurteilung exekutiver Funktionen für das Kindergartenalter (BRIEF-P) von 71 Kindergartenkindern, deren Mütter während der Schwangerschaft geraucht haben, mit einer Kontrollgruppe verglichen. Für einen Teil der Kinder von Raucherinnen $(n=42)$ und von Nichtraucherinnen $(n=27)$ konnten darüber hinaus die Erzieherinneneinschätzungen im BRIEF-P berücksichtigt werden.

Ergebnisse: Im Elternurteil ergab sich für Kinder von Raucherinnen ein gehäuftes Auftreten von Auffälligkeiten in den exekutiven Funktionen. Insbesondere im Bereich der Inhibition zeigten sich fast 4-mal häufiger klinisch relevante Defizite als für die Kinder der Kontrollgruppe $(p=0,006)$. Die Auffälligkeiten in der Inhibition zeigen sich sowohl im Eltern- als auch im Erzieherurteil.

Diskussion: Die hier beschriebene erhöhte Rate an Defiziten in den exekutiven Funktionen, insbesondere im Bereich der Inhibition, bestätigt den Forschungsstand zum Nikotinkonsum während der Schwangerschaft. Mangelnde Inhibition bzw. Impulskontrolle stellt ein Kernsymptom der ADHS dar. 


\section{Introduction}

\section{$\nabla$}

In recent years various measures have been implemented in Germany to reduce smoking and decrease the number of people in the general population who smoke. Despite these attempts, the percentage of women who smoke has remained fairly constant at $29.3 \%$. The percentage of women who smoke regularly is highest in the group aged between 18 and 29 years, where it amounts to $29.7 \%$. A further $10.3 \%$ of this age group reported that they occasionally smoked. It was found that smoking correlated with social status: women with a lower social status were far more likely to be smokers [1]. Around $10 \%$ of non-smokers were regularly exposed to nicotine in their home environment [2]. Even pregnancy does not appear to prevent many women from continuing to smoke: at least $11-13 \%$ of all pregnant women in Germany stated that they smoked at least one cigarette per day; smoking in this context was again found to be correlated to socio-economic status and age [3-5].

Many studies have shown that nicotine use during pregnancy has numerous adverse effects on both the expectant mother and the unborn child $[6,7]$. In addition to various complications of pregnancy such as preterm placental abruption, hypertension, premature delivery and miscarriage, maternal smoking during pregnancy has been found to be linked to infertility over the longer term (cf. [8] for a summary of risks). For the unborn child, maternal smoking carries an increased risk of intrauterine growth retardation (low birth weight, restricted growth) $[9,10]$ and of long-term injury to health (cf. [8] for a summary of risks); but cognitive and behavioral development were also found to be impaired by intrauterine exposure to nicotine $[6,11]$. External behavioral problems such as ADHD (Attention Deficit Hyperactivity Disorder) [12,13] or executive function deficits [14,15] have been reported in connection with maternal smoking. In a systematic review of the literature, Clifford, Lang and Chen [16] additionally demonstrated that similar effects on child development could be detected even if the mother had only been a passive smoker.

The term "executive function" comprises various higher cognitive processes which enable a person to adapt flexibly to new and complex tasks and to independently regulate the performance of activities. Executive functions include abilities such as inhibitory control, the ability to plan actions, the ability to flexibly (re-)direct attention, the ability to recognize and correct mistakes and a certain immunity to distractions [17]. Commonly listed key competences include working memory performance, inhibitory control and cognitive flexibility [18].

A number of studies have been carried out into the development of executive functioning in children, and the studies have demonstrated that executive functioning is a multidimensional construct (cf. [19] for a summary). It was not only found that the interaction between executive functioning, biological maturation and environmental experience was associated with children's readiness for school and school attainment [20], but also that socio-economic status had a significant impact on the development of these cognitive abilities [18,21].

This study examined whether it is possible to detect the impact of maternal smoking during pregnancy on executive functioning of preschool-aged children and what connection there could be to the family's socio-economic status. The study also looked at the correlation between parental perspective and the perspective of the children's preschool teachers with regard to descriptions of child behavior.

\section{Method}

$\nabla$

\section{Instruments used}

The questionnaire used in this study was the Verhaltensinventar zur Beurteilung exekutiver Funktionen für das Kindergartenalter (BRIEF-P, [22]), the German-language version of the Behavior Rating Inventory of Executive Function ${ }^{\circledR}$ - Preschool Version by Gioia, Espy and Isquith [23]. The questionnaire is designed to be completed by the child's caregivers (parents, teachers). BRIEF-P consists of 63 statements about the behavior of younger children, which can be summarized by the term "executive functioning". The caregivers used a three-point scale ("never", "sometimes", "often") to indicate whether certain behaviors (e.g.: throws a tantrum if he is told "no") constituted a problem in the past six months. The ratings by primary caregivers were used to determine characteristic behaviors in five primary areas (Inhibit, Shift, Emotional Control, Working Memory, Plan/Organize), which were then used to create three indices (Inhibitory Self-Control, Flexibility, Emergent Metacognition) as well as a General Executive Composite score. The assignment of primary rating scores from the BRIEF-P to the respective indices and to the aggregate score is shown in Fig. 1. To obtain the aggregate score, the total raw scores of the five subtests were converted into a t-value (mean $=50, \mathrm{SD}=10$ ). The respective index scores were compiled from the scores of two subtests, the subtest Emotional Control being part of both the Inhibitory Self-Control Index and the Flexibility Index.

Internal consistency of the aggregate score of the BRIEF-P was $\alpha=0.95$ for the parental rating and $\alpha=0.96$ for the rating given by teachers. Gender-specific and age-specific standard t-values are available for BRIEF-P for children from the age of $2 ; 0$ to $6 ; 11$ years.

Parents were given an additional questionnaire which included questions about the pregnancy, the birth and the child's development as well as the family's socio-economic status.

\section{Study population}

All data were collected as part of the German-language standardization of the Behavior Rating Inventory for Executive Function Preschool Version (BRIEF-P) [22]. Data collection was done from 2012 to 2013 in various daycare centers in six different German federal states under the direction of the Center for Clinical Psychology and Rehabilitation of the University of Bremen. Cooperating partners in kindergartens were contacted locally and information leaflets were handed out to preschool teachers and parents. Parents gave their consent to the use of data obtained from the questionnaire on the family's socio-economic status and the child's early development as well as the use of the behavior rating given by the kindergarten teachers.

The statistical analyses below include the BRIEF-P parental ratings for 71 children (boys: $n=35,49.3 \%$; girls: $n=36,50.7 \%$ ), whose mothers had reported on the additional parental questionnaire on the child's development and the family's socio-economic status that they had smoked during pregnancy. This study cohort was matched with 71 children from the standard BRIEF-P study population whose mothers had not smoked during pregnancy; matching was done using the characteristics "child's age" and "gender" and "maternal educational qualification".

Executive function rating scores given by preschool teachers from the respective daycare centers and obtained using the teacher version of BRIEF-P were available in addition to parental rating 

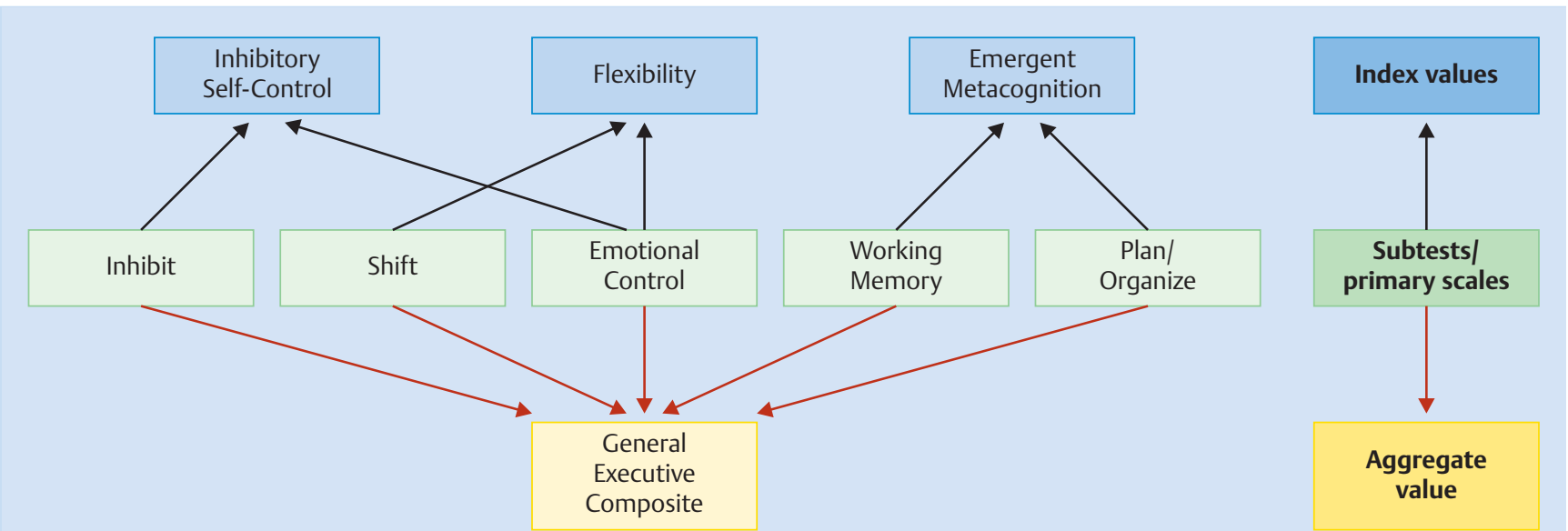

Fig. 1 Consolidation of the primary rating scores from the BRIEF-P into three index scores and an aggregate score.

scores for 69 children ( $\mathrm{n}=42$ children of smokers, $\mathrm{n}=27$ children of non-smokers).

\section{Statistical analysis}

T-test was used to assess differences between groups for significance. Cohen's d was used to determine effect sizes for differences in means of study populations of the same size. In the BRIEF-P analysis, t-values $>65$ were interpreted as suspicious. The $t$-values obtained were categorized for frequency analysis as follows: $\leq 65=0$ = unremarkable, $>65=1=$ suspicious. The odds ratio and $95 \%$ confidence interval were calculated. Chi-square test was used to verify the significance of hypotheses in crosstabulation.

The relationship between parental rating with BRIEF-P and rating by teachers using BRIEF-P was investigated. To do this, separate Pearson product-moment correlations were calculated for both groups. Differences between the correlation coefficients of both groups with regard to subtests, scales and total values were tested for significance using Fisher z-transformation. The paired correlation coefficients were then pooled. All analyses were done using SPSS Version 20.

\section{Results \\ $\nabla$}

\section{Description of the study population}

Descriptions of the study population are given in $\bullet$ Table 1 (maternal characteristics) and $\bullet$ Table $\mathbf{2}$ (characteristics of the child). Matching meant that the distribution of the characteristics "maternal educational achievement" $\left(\mathrm{X}^{2}=0.795, \mathrm{df}=2, \mathrm{p}=0.672\right)$ and "child's age" ( $t=-0.012, \mathrm{df}=140, \mathrm{p}=0.990$ ) were similar for both groups (smokers vs. non-smokers). In contrast, the distribution of the characteristic "family income" differed significantly between the smokers group and the non-smokers group. More than $75 \%$ of the mothers who smoked reported a monthly family income of less than 2500 Euros; in the control group only around $45 \%$ of families had a monthly income of less than 2500 Euros. There was also a significant difference with regard to marital status: $24(33.8 \%)$ women who smoked reported that they were single parents, while only $12(16.9 \%)$ women who reported that they did not smoke were living without a partner. This also indicates a significant association between family income and family status; mothers who were single parents were more likely to have a lower income $\left(X^{2}=17.957, \mathrm{df}=3, \mathrm{p}=0.000\right)$.

The smokers were also questioned about the number of cigarettes they smoked per day while pregnant and whether or when they had stopped smoking. The results showed that $61.2 \%$ of women in this group had smoked throughout their entire pregnancy. Those women who stopped smoking during pregnancy stopped on average towards the end of the 3rd month of pregnancy $(S D=1.9)$. The average number of cigarettes smoked was 8.6 per day $(S D=7.3$, minimum $=1$, maximum $=30$, median $=5$ ). Two smokers and one non-smoker additionally reported that they had also drunk alcohol on special occasions.

According to the parental questionnaire which looked at the child's development and the family's socio-economic status, six of the 71 mothers (8.5\%) who had smoked during pregnancy also reported that their child suffered from asthma or from another chronic respiratory disease. Based on this, the children of women who smoked had a 3.2-fold higher risk $(\mathrm{OR}=3.2,95 \% \mathrm{CI}=0.62$ 16.35) of developing a chronic respiratory illness. But according to the probability distribution (frequency of occurrence), the difference between these children $(n=2 ; 2.8 \%)$ and the children of women who did not smoke was not statistically significant $\left(X^{2}=2.119, d f=1, p=0.145\right)$. In terms of birth weight it was found that the mean birth weight of children of mothers who smoked ( mean birth weight $=3240.0, \mathrm{SD}=526.0$ ) was 125 grams lower than that of children of non-smokers (mean birth weight = $3365.0 \mathrm{SD}=551.7$ ); however, this difference was also not statistically significant (cf. O Table 2). Other investigated variables of pregnancy and birth showed no differences between groups. No differences were found between groups with regard to the developmental milestones of early childhood (in particular language acquisition).

\section{Executive function deficits in children whose mothers} smoked during pregnancy are more obvious in the area of inhibitory control

As demonstrated in O Table 3, a comparison of the mean values for parental rating using the BRIEF-P showed a significant difference for the primary scale Inhibit $(t=-2.777, d f=140, p=0.006)$. The standardized difference in means could be interpreted as a medium effect size with $d=-0.45$. The standardized differences in means for the remaining four primary scales did not differ sig- 
Table 1 Description of the study population: maternal characteristics.

\begin{tabular}{|c|c|c|c|c|c|c|c|}
\hline & \multicolumn{2}{|c|}{$\begin{array}{l}\text { Children of women who } \\
\text { smoked }(n=71)\end{array}$} & \multicolumn{2}{|c|}{$\begin{array}{l}\text { Children of women who } \\
\text { did not smoke }(n=71)\end{array}$} & \multirow[b]{2}{*}{$x^{2}$} & \multirow[b]{2}{*}{ df } & \multirow[b]{2}{*}{$\mathbf{p}$} \\
\hline & $\mathbf{n}$ & $\%$ & $\mathbf{n}$ & $\%$ & & & \\
\hline Maternal educational level & & & & & 0.795 & 2 & 0.672 \\
\hline no qualifications/certificate of secondary education & 29 & 40.8 & 26 & 36.6 & & & \\
\hline D intermediate school-leaving certificate/POS & 31 & 43.7 & 30 & 42.3 & & & \\
\hline $\begin{array}{l}\text { entrance qualification for advanced technical college } \\
\text { or university }\end{array}$ & 11 & 15.5 & 15 & 21,1 & & & \\
\hline Marital status & & & & & 5.358 & 1 & 0.021 \\
\hline single parent & 24 & 33.8 & 12 & 16.9 & & & \\
\hline Monthly family income (in Euros) & & & & & 15.097 & 3 & 0.002 \\
\hline$><1000$ & 11 & 16.2 & 8 & 12.3 & & & \\
\hline - $1000-2500$ & 41 & 60.3 & 21 & 32.3 & & & \\
\hline - $2500-5000$ & 15 & 22.1 & 31 & 47.7 & & & \\
\hline$>>5000$ & 1 & 1.5 & 5 & 7.7 & & & \\
\hline Marital status X income & & & & & 17.957 & 3 & 0.000 \\
\hline
\end{tabular}

Note: $\mathrm{POS}=$ general polytechnic secondary school certificate (school-leaving certificate of the GDR, corresponds to intermediate school leaving certificate), $\mathrm{t}=\mathrm{t}$-value, $\mathrm{df}=$ degrees of freedom, $p=$ two-tailed significance test

Table 2 Description of the study population: children's characteristics.

\begin{tabular}{|c|c|c|c|c|c|c|c|}
\hline & \multicolumn{2}{|c|}{$\begin{array}{l}\text { Children of women who } \\
\text { smoked }(n=71)\end{array}$} & \multicolumn{5}{|c|}{$\begin{array}{l}\text { Children of women who } \\
\text { did not smoke }(n=71)\end{array}$} \\
\hline & mean & SD & mean & SD & $\mathbf{t}$ & df & $\mathbf{p}$ \\
\hline Age (in months) & 57.2 & 14.4 & 57.2 & 13.7 & -0.012 & 140 & 0.990 \\
\hline \multirow[t]{2}{*}{ Birth weight (in grams) } & 3240.0 & 526.0 & 3365.0 & 551.7 & 1.372 & 140 & 0.172 \\
\hline & $\mathbf{N}$ & $\%$ & N & $\%$ & $x^{2}$ & df & p \\
\hline Chronic respiratory disease & 6 & 8.5 & 2 & 2.8 & 2.119 & 1 & 0.145 \\
\hline
\end{tabular}

Note: $\mathrm{t}=\mathrm{t}$-value, $\mathrm{df}=$ degrees of freedom, $\mathrm{p}=$ two-tailed significance test

Table 3 Differences in parental assessment (BRIEF-P) of children's executive functioning between the children of mothers who smoked and the children of nonsmokers.

\begin{tabular}{|c|c|c|c|c|c|c|c|c|c|}
\hline & \multicolumn{2}{|c|}{$\begin{array}{l}\text { Children of women who } \\
\text { did not smoke }(n=71)\end{array}$} & \multicolumn{2}{|c|}{$\begin{array}{l}\text { Children of women who } \\
\text { smoked }(n=71)\end{array}$} & \multirow[b]{2}{*}{ Diff } & \multirow[b]{2}{*}{$t$} & \multirow[b]{2}{*}{ df } & \multirow[b]{2}{*}{$\mathbf{p}$} & \multirow[b]{2}{*}{ d } \\
\hline & mean & SD & mean & SD & & & & & \\
\hline Inhibit & 50.4 & 9.5 & 55.0 & 10.1 & -4.6 & -2.777 & 140 & 0.006 & -0.45 \\
\hline Shift & 49.0 & 9.5 & 50.5 & 11.0 & -1.5 & -0.865 & 140 & 0.388 & -0.14 \\
\hline Emotional Control & 48.9 & 10.1 & 51.5 & 10.5 & -2.6 & -1.519 & 140 & 0.131 & -0.25 \\
\hline Working Memory & 51.2 & 10.2 & 53.7 & 10.7 & -2.5 & -1.416 & 140 & 0.159 & -0.23 \\
\hline Plan/Organize & 50.4 & 10.5 & 52.6 & 10.1 & -2.2 & -1.281 & 140 & 0.202 & -0.22 \\
\hline $\mathrm{ISCl}$ & 50.0 & 9.1 & 54.2 & 10.0 & -4.2 & -2.608 & 140 & 0.010 & -0.42 \\
\hline $\mathrm{FI}$ & 48.8 & 9.6 & 51.3 & 10.7 & -2.5 & -1.437 & 140 & 0.153 & -0.23 \\
\hline EMI & 51.2 & 10.2 & 53.4 & 10.4 & -2.3 & -1.305 & 140 & 0.194 & -0.22 \\
\hline GEC & 50.3 & 10.1 & 53.8 & 10.1 & -3.5 & -2.060 & 140 & 0.041 & -0.34 \\
\hline
\end{tabular}

Note: ISCI = Inhibitory Self-Control Index, FI = Flexibility Index, EMI = Emergent Metacognition Index, GEC = General Executive Composite, Diff = difference in means, t = t-value, $\mathrm{df}=$ degrees of freedom, $\mathrm{p}=$ two-tailed test, with the analysis of index values and aggregate values done based on subscales but without adjusting the level of significance for multiple testing, $d=$ effect size

nificantly. However, analysis of the higher-level index scores showed that the standardized difference in means for Inhibitory Self-Control was statistically significant $(t=2.608, d f=140$, $\mathrm{p}=0.010)$. This index combines the two primary scales Inhibit and Emotional Control (cf. $\odot$ Fig. 1). Here too, the effect size was medium $(\mathrm{d}=-0.42)$. The standardized difference in means calculated for the General Executive Composite was also statistically significant $(\mathrm{t}=-2.060, \mathrm{df}=140, \mathrm{p}=0.041)$, although the effect size $(d=-0.34)$ was smaller than of the two above-mentioned differences. The aggregate score incorporates all five primary scales.

In a clinical context t-values $>65$ are interpreted as suspicious. A corresponding classification of t-values into the categories "suspicious" or "unremarkable" resulted in a greater percentage of suspicious values for the children of women who had smoked compared to the children from the control group in almost all areas (primary scales, indices) (cf. $\bigcirc$ Table 4).

This difference was particularly evident and significant for the scale Inhibit: $18.3 \%(\mathrm{n}=13)$ of the children of mothers who had 
Table 4 Incidence of clinically suspicious ratings (t-value > 65) for children of women who smoked and children of women who did not smoke using the BRIEF-P.

\begin{tabular}{|c|c|c|c|c|c|c|c|c|c|}
\hline & \multicolumn{2}{|c|}{$\begin{array}{l}\text { Children of women who } \\
\text { did not smoke }(n=71)\end{array}$} & \multicolumn{7}{|c|}{$\begin{array}{l}\text { Children of women who } \\
\text { smoked }(n=71)\end{array}$} \\
\hline & $\mathbf{n}$ & $\%$ & $\mathbf{n}$ & $\%$ & $x^{2}$ & $\mathbf{p}$ & OR & $\mathrm{Cl}(95$ & \\
\hline Inhibit & 4 & 5.6 & 13 & 18.3 & 5.413 & 0.020 & 3.75 & 1.16 & 12.15 \\
\hline Shift & 2 & 2.8 & 7 & 9.9 & 2.966 & 0.085 & 3.77 & 0.76 & 18.84 \\
\hline Emotional Control & 6 & 8.5 & 5 & 7.0 & 0.099 & 0.754 & 0.8 & 0.24 & 2.82 \\
\hline Working Memory & 7 & 9.9 & 9 & 12.7 & 0.282 & 0.596 & 1.3 & 0.47 & 3.78 \\
\hline Plan/Organize & 7 & 9.9 & 7 & 9.9 & 0.000 & 1.000 & 1.0 & 0.33 & 3.01 \\
\hline $\mathrm{ISCl}$ & 4 & 5.6 & 11 & 15.5 & 3.652 & 0.056 & 3.1 & 0.93 & 10.16 \\
\hline $\mathrm{FI}$ & 4 & 5.6 & 6 & 8.5 & 0.430 & 0.512 & 1.6 & 0.42 & 5.73 \\
\hline EMI & 7 & 9.9 & 9 & 12.7 & 0.282 & 0.596 & 1.3 & 0.47 & 3.78 \\
\hline GEC & 5 & 7.0 & 12 & 16.9 & 3.274 & 0.070 & 2.7 & 0.89 & 8.07 \\
\hline
\end{tabular}

Note: ISCI = Inhibitory Self-Control Index, FI = Flexibility Index, EMI = Emergent Metacognition Index, GEC = General Executive Composite, $x^{2}=x^{2}$-value, $p=$ two-tailed significance test, $\mathrm{OR}=$ odds ratio, $\mathrm{Cl}=$ confidence interval.

Table 5 Differences in executive functions between the children of women who smoked and the children of non-smokers according to the ratings made by teachers using the BRIEF-P.

\begin{tabular}{|c|c|c|c|c|c|c|c|c|c|}
\hline & \multicolumn{2}{|c|}{$\begin{array}{l}\text { Children of women who } \\
\text { did not smoke }(n=27)\end{array}$} & \multicolumn{2}{|c|}{$\begin{array}{l}\text { Children of women who } \\
\text { smoked }(n=42)\end{array}$} & \multirow[b]{2}{*}{ Diff } & \multirow[b]{2}{*}{$\mathbf{T}$} & \multirow[b]{2}{*}{ df } & \multirow[b]{2}{*}{$\mathbf{p}$} & \multirow[b]{2}{*}{ d } \\
\hline & mean & mean & mean & SD & & & & & \\
\hline Inhibit & 51.0 & 51.0 & 55.2 & 11.2 & -4.2 & -1.511 & 67 & 0.135 & -0.38 \\
\hline Shift & 52.2 & 52.2 & 50.2 & 9.7 & 2.0 & 0.837 & 67 & 0.406 & 0.21 \\
\hline Emotional Control & 52.1 & 52.1 & 52.3 & 9.9 & -0.2 & -0.093 & 67 & 0.926 & -0.02 \\
\hline Working Memory & 54.0 & 54.0 & 54.6 & 9.6 & -0.6 & -0.226 & 67 & 0.822 & -0.05 \\
\hline Plan/Organize & 54.3 & 54.3 & 53.3 & 9.9 & 1.0 & 0.339 & 67 & 0.736 & 0.09 \\
\hline $\mathrm{ISCl}$ & 51.7 & 51.7 & 54.5 & 11.1 & -2.8 & -1.015 & 67 & 0.314 & -0.25 \\
\hline $\mathrm{FI}$ & 52.3 & 52.3 & 51.6 & 9.4 & 0.7 & 0.304 & 67 & 0.762 & 0.07 \\
\hline EMI & 54.3 & 54.3 & 54.5 & 9.7 & -0.2 & -0.05 & 67 & 0.960 & -0.02 \\
\hline GEC & 53.1 & 53.1 & 54.5 & 10.1 & -1.4 & -0.516 & 67 & 0.608 & -0.13 \\
\hline
\end{tabular}

Note: ISCI = Inhibitory Self-Control Index, FI = Flexibility Index, EMI = Emergent Metacognition Index, GEC = General Executive Composite, Diff = difference in means, $\mathrm{t}=\mathrm{t}$-value, $\mathrm{df}=$ degrees of freedom, $\mathrm{p}=$ two-tailed test, with the analysis of index values and aggregate values done based on subscales but without adjusting the level of significance for multiple testing, $d=$ effect size.

smoked during pregnancy were assessed as clinically problematic; however, only $4.6 \%$ of children in the control group $(n=4)$ were assessed as clinically problematic. The incidence of suspicious findings in the Inhibit scale was 3.8 times higher for children of mothers who smoked compared to the control group $(\mathrm{OR}=3.8,95 \% \mathrm{CI}=1.16-12.15)$. Similarly, there were also more suspicious findings in the primary scale Shift for the children of mothers who smoked. The odds ratio was also 3.8, even though only 7 (9.9\%) of children were assessed as problematic. However, the difference in the distribution of values was not statistically significant. The odds ratio for the higher-level scale Inhibitory Self-Control was 3.1, indicating a higher rate of deficits among the children of mothers who smoked which narrowly missed statistical significance $(p=0.056)$. Findings were similar for the General Executive Composite score $(\mathrm{OR}=2.7, \mathrm{p}=0.070)$.

\section{Ratings by teachers also found more deficits in} inhibition/impulse control in children of smokers

As not all children were assessed by their teacher with regard to executive functioning and as the sizes of the groups "children of smokers" and "children of non-smokers" differed, the following analyses must be interpreted with care. Analysis showed teacher ratings followed similar patterns to those of parental rating with regard to means and the distribution of suspicious t-values. None of the analyses found statistically significant differences (cf. @ Table 5).

But the teachers' assessments also clearly showed that there were more suspicious findings in the primary scale Inhibit among the children of mothers who had smoked than for the children of non-smoking mothers. The difference in means between both groups is half a standard deviation and is thus within similar ranges as the difference in means in the parental assessment (difference in parental assessment $=4.6$ vs. difference in teachers' assessment $=4.2$ ).

\section{Parental and teacher ratings of executive functions show medium to high agreement}

As executive functioning was assessed by teachers for part of the study population, it is possible to comment on the agreement between parental and teacher assessments. The differences in correlation coefficients between parental and teachers' assessment, which were initially calculated separately for both groups (children of smoking mothers vs. children of non-smoking mothers), were not statistically significant, meaning that the coefficient which was calculated for the total study population $(n=142)$ can be used. 
Table 6 Correlation between parental rating and teachers' rating of executive functioning (BRIEF-P).

\begin{tabular}{|c|c|c|c|c|c|c|c|}
\hline & \multicolumn{2}{|c|}{$\begin{array}{l}\text { Children of mothers who } \\
\text { smoked }(n=42)\end{array}$} & \multicolumn{5}{|c|}{$\begin{array}{l}\text { Children of mothers who did } \\
\text { not smoke }(n=27)\end{array}$} \\
\hline & $r_{1}$ & $\mathbf{p}$ & $r_{2}$ & $\mathbf{p}$ & $\mathbf{p}^{\mathbf{a}}$ & $r_{12}{ }^{b}$ & $r_{n}$ \\
\hline Inhibit & 0.51 & 0.007 & 0.54 & 0.000 & 0.879 & 0.53 & 0.55 \\
\hline Shift & 0.34 & 0.079 & 0.48 & 0.002 & 0.518 & 0.43 & 0.45 \\
\hline Emotional Control & 0.25 & 0.203 & 0.23 & 0.152 & 0.929 & 0.24 & 0.35 \\
\hline Working Memory & 0.78 & 0.000 & 0.59 & 0.000 & 0.162 & 0.67 & 0.60 \\
\hline Plan/Organize & 0.62 & 0.001 & 0.35 & 0.029 & 0.167 & 0.47 & 0.49 \\
\hline $\mathrm{ISCl}$ & 0.59 & 0.001 & 0.55 & 0.000 & 0.844 & 0.56 & 0.52 \\
\hline $\mathrm{FI}$ & 0.39 & 0.046 & 0.36 & 0.022 & 0.908 & 0.37 & 0.43 \\
\hline EMI & 0.74 & 0.000 & 0.54 & 0.000 & 0.202 & 0.63 & 0.58 \\
\hline GEC & 0.68 & 0.000 & 0.53 & 0.000 & 0.346 & 0.59 & 0.56 \\
\hline
\end{tabular}

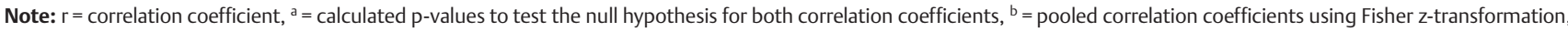
$r_{n}=$ correlation coefficient of the standardization sample population, ISCI = Inhibitory Self-Control Index, FI = Flexibility Index, EMI = Emergent Metacognition Index, GEC = General Executive Composite.

With the exception of the primary scale Emotional Control there was a medium to high linear correlation between groups (cf. - Table 6), which points to a good correlation between parental and teacher assessment of most aspects of executive functioning. But these findings should be interpreted with care, as ratings by both parents and teachers were not available for all children in the study population.

\section{Discussion}

\section{$\nabla$}

The results of this study into the cognitive and behavioral development of children of mothers who smoked indicate that maternal nicotine use during pregnancy has a negative impact on various aspects of the child's executive functions. According to the parental assessment, the children of mothers who smoked had higher mean t-values in all scales of the BRIEF-P. The difference to the group of children of non-smoking mothers was up to half a standard deviation (particularly for the primary scale Inhibit). The questions listed in the scale Inhibit describe the child's ability to regulate his/her own behavior, i.e., the child's ability to inhibit its own impulses and stop its own behavior. Limited ability to self-regulate is considered to be one of the core deficits associated with attention deficit/hyperactivity disorder [24]. It can therefore be assumed that there is a relationship between nicotine use during pregnancy, deficits in executive functioning and ADHD, as not all aspects of executive functioning are equally impaired in children with ADHD [25]. The most obvious relationship between executive functioning and ADHD is with regard to impulse control, i.e., inhibition. The relationship between executive function and ADHD is already well documented for schoolage children; however there is far less research available for preschool-aged children. In their study of 160 preschool children, Sonuga-Barke et al. [26] showed that there was an association with ADHD, particularly for tasks measuring impulse control. No significant associations were found between ADHD and other aspects of executive function such as working memory or planning. The findings of our study which were based on parental and teacher assessments obtained with BRIEF-P indicate a similar scenario. As both parental and teacher assessments came to similar results with regard to the child's level of impulse control/inhibition, it must be concluded that the reduced impulse control was a general behavioral problem which occurred in a number of different settings. This satisfies a further criterion for the diag- nosis of ADHD: symptoms must occur in different situations; thus, deficits such as a lack of inhibition/impulse control must be observed both at home and elsewhere (in this case, in kindergarten). Another diagnostic criterion of ADHD is that the symptoms must be present prior to the age of 7 years.

In addition, Sonuga-Barke and colleagues [26] were able to show a positive correlation between deficits in inhibition and the severity of ADHD. Another recent study also found a clear association between ADHD and deficits in central areas of executive functioning, once again in the area of inhibition/impulse control [27]. Skogan and colleagues conjectured that there could be a connection between deficits in executive functions and various behavioral disorders, whereby the behavioral problems reported in school-age children developed from executive function deficits already identifiable at preschool age. BRIEF-P could be used in this context as a way to detect these preschool indications for subsequent behavioral problems.

Roberts, Martel and Nigg [28] showed that executive function deficits can be used to differentiate and describe subtypes of ADHD. The authors were able to identify three groups who could be differentiated from one another based on either (1) lower ability to shift attention flexibly, (2) poor inhibitory control, or (3) unremarkable executive functioning.

If it can be assumed that deficits in inhibitory control or impulse control are predictors for ADHD, then the conclusion for our study is that children of mothers who smoked during pregnancy are at higher risk of ADHD compared to children of non-smokers. This applies above all to the subtype of ADHD associated with deficits in inhibitory control.

However, it is not possible to assert a causal relationship between prenatal factors such as maternal nicotine use during pregnancy and the postnatal development of children in various areas (here: inhibitory deficits as a sub-area of executive function) based on the results presented in this study. The problem is that mothers who smoke during pregnancy may also have a number of additional risk factors which can negatively affect the child's development. These can include nutritional behavior or health behavior [11]. However, there does appear to be an association between maternal nicotine use and deficits in the child's inhibitory control. But whether nicotine use itself is responsible for the deficits or whether the deficits are due to genetic predisposition [29], other environmental toxins such as PCB or lead [30] or are facilitated by characteristics such as the family's socio-economic status is still being discussed. Millenet et al. [31] also assumed that 
interactions between genetic and various environmental factors could contribute to ADHD. Various studies have reported an association between prenatal exposure to nicotine through the mother and important neurobiological changes in prenatal brain maturation [32-34], which could create a basis for cognitive and behavioral problems. Dwyer and colleagues [35] have described in detail the changes in prenatal brain development caused by nicotine. Because of its similarity to the neurotransmitter acetylcholine, nicotine stimulates the nicotinergic acetylcholine receptors, which in turn affect heart beat and blood pressure. Nicotine also has an indirect influence on the number of nerve cells in the brain, as nicotine prematurely terminates the proliferation phase of nerve cells [36]. Nicotine also negatively influences the development of dopaminergic neurons [37], which are responsible for motion control and behavioral control. Dopamine is considered to be an important factor in the etiology of ADHD; the hypothesis that patients with ADHD have lower dopamine concentrations in the synaptic gap is considered proven (for a summary of this point, cf. [38]).

The results of our study are in accordance with the findings of the studies discussed above. Assessments by both parents and preschool teachers reported deficits in inhibitory control already in preschool-aged children, i.e. at an early stage before reaching the age of seven, for children of mothers who had smoked during pregnancy. This early point in time indicates that the causes are more likely to be primarily biological rather than due to postnatal factors.

It can safely be assumed that the deficits in impulse control as a consequence of maternal nicotine use during pregnancy will have a negative impact on the child's further development. Studies have shown that executive function deficits in school-age children lead to poorer performance in other areas of cognitive functioning (for a review, cf. [39]).

Medical secondary findings for our study population showed that the children of smoking mothers had both a lower birth weight and a higher risk of developing respiratory disease compared to the children of non-smoking mothers. The difference between groups did not achieve statistical significance, but this tendency was in agreement with the results of other studies [8-10].

The small size of the study population is a limitation for the interpretation of data, as it did not permit the inclusion of further variables which could have been used for multivariate analysis. Another limitation was the interview method used: data on nicotine use was obtained only from a parental questionnaire; the reliability and accuracy of the information provided on smoking behavior during pregnancy must therefore be scrutinized carefully. In addition, detailed information is lacking on whether during pregnancy the mother was exposed to secondhand smoke and whether the child was exposed postnatally to secondhand smoke and what the further conditions of development were like.

\section{Conclusions for Clinical Practice}

$\nabla$

The findings provide a starting point for prevention and intervention. Preventive measures would primarily focus on nicotine use during pregnancy. In this context it would be necessary to gather data on nicotine use already during the prenatal care of pregnant women, not simply as a risk factor but differentiated according to daily nicotine dose, to provide suitable advice to the mother. The German Federal Center for Health Education (www. bzga.de) has issued a number of brochures for pregnant women, mothers and their partners, available (in German) from their website (www.bzga.de) under the heading Förderung des Nichtrauchens (Promoting Non-smoking) to inform mothers and help them find a way to stop smoking. The German National Center for Early Support (Nationales Zentrum Frühe Hilfen, NZFH) also provides various support systems and coordinated offers of assistance (such as health visitors) for parent and children (www.frühehilfen.de). A number of projects aimed at pregnant women have been launched in different federal states in Germany; one example of this is the project PATERAS (Promotion of Smoking Cessation during Pregnancy and in the First Year after Birth) in Hamburg [40]. It would be useful if the prevention strategies to promote non-smoking tailored to the needs of the individual pregnant woman and to protect the mother from inhaling secondhand smoke during pregnancy were addressed across all of Germany and the necessary measures implemented [41]. Similarly, it would also be useful if the information on prevention and the support for stopping smoking not only targeted women when they were pregnant but also included the time after giving birth. It would be worth investigating whether and in which form information on nicotine use by pregnant women (and of her partner, if necessary) could be passed on to the child's pediatrician in a case form or doctor's letter. The law on Cooperation and Information in Child Protection, passed on December 22, 2011 (BGBl. I S. 2975), could serve as the basis for this cooperation. Intervention measures targeting pregnant women have been shown to have at least a short-term effect [42] but clearly these measures still do not reach enough women. Moreover, despite all the information, women are given different, often contradictory information on smoking behavior. In the conclusion to their study, Rasenack and Jähne [43] described various measures to provide information to pregnant women, including improving the understanding of addiction by medical staff, particularly gynecologists.

When considering the behavioral problems of the children, several studies have confirmed that behavior therapy had a positive impact on executive functioning, particularly inhibitory control [44]. Improving self-regulation, specifically cognitive control, played an important role. Cognitive control is a subsystem of self-regulation and is significantly defined by executive function. Gawrilow et al. [45] reported that training sessions using socalled if-then planning as a strategy for self-regulation and to inhibit reactions resulted in improved inhibitory performance in children with ADHD. Early intervention could help prevent secondary impairment during the child's subsequent development, particularly during school lessons [46].

\section{Conflict of Interest}

$\nabla$

None.

\section{References}

1 Lampert T, von der Lippe E, Müters S. Verbreitung des Rauchens in der Erwachsenenbevölkerung in Deutschland. Bundesgesundheitsblatt 2013; 56: 802-808

2 Kröger C, Mons U, Klärs G et al. Evaluation des Gesundheitsziels „Tabakkonsum reduzieren“. Bundesgesundheitsblatt Gesundheitsforschung Gesundheitsschutz 2010; 53: 91-102

3 Schneider S, Maul H, Freerksen $N$ et al. Who smokes during pregnancy? An analysis of the German Perinatal Quality Survey 2005. Public Health 2008; $122: 1210-1216$ 
4 Fleitmann S, Dohnke B, Balke K et al. Frauen und Rauchen. Bundesgesundheitsblatt Gesundheitsforschung Gesundheitsschutz 2010; 53 : 117-124

5 Scholz R, Voigt M, Schneider $K$ et al. Analysis of the German Perinatal Survey of the years 2007-2011 and comparison with data from 19951997: Maternal characteristics. Geburtsh Frauenheilk 2013; 73: 1247

6 Julvez J, Ribas-Fito N, Torrent M et al. Maternal smoking habits and cognitive development of children at age 4 years in a population-based birth cohort. Int J Epidemiol 2007; 36: 825-832

7 Danielsson J, de Boer M, Petermann $F$ et al. Nikotinexposition in der Schwangerschaft - Auswirkungen auf die kognitive Entwicklung im Kindergartenalter. Geburtsh Frauenheilk 2009; 69: 692-697

8 Mund M, Louwen F, Klingelhoefer D et al. Smoking and pregnancy - a review on the first major environmental risk factor of the unborn. Int J Environ Res Public Health 2013; 10: 6485-6499

9 Koch S, Vilser C, Groß W et al. Rauchen während der Schwangerschaft Risiko für intrauterine Wachstumsrestriktion und bleibende Kleinwüchsigkeit. Z Geburtshilfe Neonatol 2012; 216: 77-81

10 Murphy DJ, Dunney C, Mullally A et al. Population-based study of smoking behaviour throughout pregnancy and adverse perinatal outcomes. Int J Environ Res Public Health 2013; 10: 3855-3867

11 Knopik VS. Maternal smoking during pregnancy and child outcomes: Real or spurious effect? Dev Neuropsychol 2009; 34: 1-36

12 Thakur GA, Sengupta SM, Grizenko N et al. Maternal smoking during pregnancy and ADHD: a comprehensive clinical and neurocognitive characterization. Nicotine Tob Res 2013; 15: 149-157

13 Huijbregts SCJ, Séguin JR, Zoccolillo $M$ et al. Associations of maternal prenatal smoking with early childhood physical aggression, hyperactivity-impulsivity, and their co-occurrence. J Abnorm Child Psychol 2007; 35: 203-215

14 Piper BJ, Corbett SM. Executive function profile in the offspring of women that smoked during pregnancy. Nicotine Tob Res 2012; 14: 191-199

15 Huijbregts SCJ, Warren AJ, de Sonneville LMJ et al. Hot and cool forms of inhibitory control and externalizing behavior in children of mothers who smoked during pregnancy: an exploratory study. J Abnorm Child Psychol 2008; 36: 323-333

16 Clifford A, Lang L, Chen R. Effects of maternal cigarette smoking during pregnancy on cognitive parameters of children and young adults: a literature review. Neurotoxicol Teratol 2012; 34: 560-570

17 Carlson SM. Developmentally sensitive measures of executive function in preschool children. Dev Neuropsychol 2005; 28: 595-616

18 Sarsour K, Sheridan M, Jutte D et al. Family socioeconomic status and child executive functions: the roles of language, home environment, and single parenthood. J Int Neuropsychol Soc 2010; 17: 120-132

19 Röthlisberger M, Neuenschwander R, Michel E et al. Exekutive Funktionen: Zugrundeliegende kognitive Prozesse und deren Korrelate bei Kindern im späten Vorschulalter. Z Entwicklungspsychol Padagog Psychol 2010; 42: 99-110

20 Neuenschwander R, Röthlisberger M, Cimeli P et al. How do different aspects of self-regulation predict successful adaptation to school? J Exp Child Psychol 2012; 113: 353-371

21 Jednoróg K, Altarelli I, Monzalvo Ket al. The influence of socioeconomic status on children's brain structure. PLoS One 2012; 7: e42486

22 Daseking $M$, Petermann $F$. Verhaltensinventar zur Beurteilung exekutiver Funktionen für das Kindergartenalter (BRIEF-P). Deutschsprachige Adaptation des Behavior Rating Inventory of Executive function Preschool Version (BRIEF-P) von G. A. Gioia, K. A. Espy \& P. K. Isquith. Bern: Huber; 2013

23 Gioia GA, Espy KA, Isquith PK. Behavior Rating Inventory of Executive Function - Preschool version (BRIEF-P). Odessa, FL: PAR; 2003

24 Barkley RA. Behavioral inhibition, sustained attention, and executive functions: constructing a unifying theory of ADHD. Psychol Bull 1997; 121: 65-94
25 Willcutt EG, Doyle AE, Nigg JT et al. Validity of the executive function theory of attention-deficit/hyperactivity disorder: a meta-analytic review. Biol Psychiatry 2005; 57: 1336-1346

26 Sonuga-Barke EJ, Dalen L, Daley D et al. Are planning, working memory, and inhibition associated with individual differences in preschool ADHD symptoms? Dev Neuropsychol 2002; 21: 255-272

27 Skogan AH, Zeiner P, Egeland J et al. Inhibition and working memory in young preschool children with symptoms of ADHD and/or oppositional-defiant disorder. Child Neuropsychol 2014; 20: 607-624

28 Roberts BA, Martel MM, Nigg JT. Are there executive dysfunction subtypes within ADHD? J Atten Disord 2013; DOI: 10.1177/ 1087054713510349

29 Thapar A, Rice F, Hay D et al. Prenatal smoking might not cause attention-deficit/hyperactivity disorder: evidence from a novel design. Biol Psychiatry 2009; 66: 722-727

30 Nigg JT, Nikolas M, Mark Knottnerus G et al. Confirmation and extension of association of blood lead with attention-deficit/hyperactivity disorder (ADHD) and ADHD symptom domains at population-typical exposure levels. J Child Psychol Psychiatry 2010; 51: 58-65

31 Millenet S, Hohmann S, Poustka L et al. Risikofaktoren und frühe Vorläufersymptome der Aufmerksamkeitsdefizit-/Hyperaktivitätsstörung (ADHS). Kindh Entwickl 2013; 22: 201-208

32 Slotkin TA, Card J, Stadler A et al. Effects of tobacco smoke on PC12 cell neurodifferentiation are distinct from those of nicotine or benzo [a]pyrene. Neurotoxicol Teratol 2014; 43: 19-24

33 Rauh VA, Horton MK, Miller RL et al. Neonatology and the environment: early exposure to airborne environmental toxicants. Neoreviews 2010; 11: e363-e369

34 Wessels C, Winterer G. Nikotin und Gehirnentwicklung. Nervenarzt 2008; 79: 7-16

35 Dwyer JB, McQuown SC, Leslie FM. The dynamic effects of nicotine on the developing brain. Pharmacol Ther 2009; 122: 125-139

36 Dani JA. Overview of nicotinic receptors and their roles in the central nervous system. Biol Psychiatry 2001; 49: 166-174

37 Azam L, Chen Y, Leslie FM. Developmental regulation of nicotinic acetylcholine receptors within midbrain dopamine neurons. Neurosci 2007; 144: $1347-1360$

38 Steinmann E, Siniatchkin M, Petermann $F$ et al. ADHS im Kindesalter: ätiologische und therapeutische Ansätze mit dem Schwerpunkt der Bildgebung. Z Neuropsychol 2012; 23: 193-203

39 Chen R, Clifford A, Lang L et al. Is exposure to secondhand smoke associated with cognitive parameters of children and adolescents?-a systematic literature review. Ann Epidemiol 2013; 23: 652-661

40 Krug B, Haasen C, Schlankardt M. PATERAS - ein Hamburger Praxisprojekt zur Förderung des Nichtrauchens in Schwangerschaft und Säuglingszeit. Suchttherapie 2008; 9: 22-25

41 Fleitmann S, Dohnke B, Balke $K$ et al. Frauen und Rauchen. Bundesgesundheitsblatt 2010; 53: 117-124

42 Nuesslein TG, Struwe A, Maiwald $N$ et al. Mütterlicher Tabakkonsum lässt sich durch einfache Intervention des Kinderarztes reduzieren. Klin Padiatr 2006; 218: 283-286

43 Rasenack R, Jähne A. Tabakkonsum und Tabakentwöhnung in der Schwangerschaft. Sucht 2010; 56: 183-196

44 Toussaint A, Petermann F, Schmidt $S$ et al. Wirksamkeit verhaltenstherapeutischer Maßnahmen auf die Aufmerksamkeits- und Exekutivfunktionen bei Kindern und Jugendlichen mit ADHS. Z Klin Psychol Psychiatr Psychother 2011; 59: 25-36

45 Gawrilow C, Schmitt K, Rauch W. Kognitive Kontrolle und Selbstregulation bei Kindern mit ADHS. Kindh Entwickl 2011; 20: 41-48

46 Gawrilow C, Petermann F, Schuchardt K. ADHS im Vorschulalter. Kindh Entwickl 2013; 22: 189-192 